\title{
Review
}

\section{Pathogenesis of Acute Graft-Versus-Host Disease: Cytokines and Cellular Effectors}

\author{
JAMES L.M. FERRARA
}

\begin{abstract}
The pathogenesis of acute graft versus host disease (GVHD) is multistep process. This review considers acute GVHD in three sequential steps: conditioning regimen, donor $T$ cell activation, and effector mechanisms. In step one, the conditioning regimen simultaneously damages and activates host tissues, amplifying antigen presentation to allogeneic donor $T$ cells. In step two, donor $T$ cells, activated by host alloantigens, proliferate and secrete a variety of cytokines. Type 1 cytokines (interleukin-2 and interferon- $\gamma$ ) are critical for acute GVHD, but several regulatory mechanisms of tissue damage include inflammatory cytokines and cytolytic cellular effectors. The gastrointestinal (GI) tract is a principal target organ because damage to the GI mucosa can release inflammatory mediators such as endotoxin that amplify systemic disease. The inflammatory processes of acute GVHD can be considered as a distortion of the cellular responses to viral and bacterial infections. Cell-mediated toxicity is critical to other GVHD target organs, particularly the liver, where Fas-mediated injury predominates. The cytolytic pathways (e.g., perforin) clearly intensify acute GVHD, although they are not necessary for systemic disease in several model systems. Many of these insights come from animal models using mutant mouse strains that can clarify the role of individual proteins or cell types in the disease process. These insights should allow the testing of new classes of drugs and inhibitors in clinical bone marrow transplantation.
\end{abstract}

\section{INTRODUCTION}

$\mathbf{O}$ UR UNDERSTANDING OF THE PATHOPHYSIOLOGY of graft-versus-host disease (GVHD) has improved greatly with recent advances in our understanding of the cellular and humoral interactions that are intrinsic to all inflammatory processes. In allogeneic bone marrow transplantation (BMT), donor lymphocytes are infused into a host that has been profoundly damaged. The pathophysiology of acute GVHD may be considered to be a distortion of the cellular response to viral and Gram-negative bacterial infections. The principal target organs of GVHD support suggest a close relationship between infection and GVHD. The skin, gut, and liver all share an extensive exposure to endotoxin and other bacterial products that can trigger and amplify local inflammation. This exposure distinguishes them from organs like the heart and kidneys that are not GVHD targets. Because of their situation as primary barriers to infection, these target organs have large populations of professional antigen-presenting cells (APCs) such as macrophages and dendritic cells that may enhance the graft-versus-host $(\mathrm{GVH})$ reaction.

Professor of Medicine and Pediatrics, Director, Combined BMT Program, University of Michigan Cancer Center, Ann Arbor, MI 48109-0942. 


\section{PHASE ONE: HOST TISSUE DAMAGE FROM CHEMORADIOTHERAPY}

Recent findings implicate the excessive production of cytokines, which are the central regulatory molecules of the immune system, as well as cellular effectors in the induction and maintenance of experimental and clinical GVHD (1-3). The pathophysiology of acute GVHD can be considered in a framework of three sequential phases $(1,3)$. The first phase is not strictly part of GVHD because it starts before the donor cells are infused. The transplant conditioning regimen damages and activates host tissues, including the intestinal mucosa, liver, and other tissues. Activated host cells secrete inflammatory cytokines, such as tumor necrosis factor (TNF)- $\alpha$ and interleukin (IL)-1 (4), and grow th factors such as granulocyte-machrophage colony-stimulating factor (GM-CSF) (5-7). The presence of inflammatory cytokines during this phase may upregulate adhesion molecules (8) and major histocompatibility complex (MHC) antigens (9-13), thereby enhancing the recognition of host MHC or minor histocompatibility antigens by mature donor $\mathrm{T}$ cells after the cellular component of the graft is infused. Increased expression of cell-surface adhesion molecules may also occur (14-16). The relationship between conditioning intensity, inflammatory cytokines, and GVHD severity was recently further supported in animal models (17). Moreover, the risk of inducting severe acute GVHD appears to be less if the lymphocytes are infused well after the primary tissue injury has resolved $(18,19)$.

\section{PHASE TWO: DONOR T-CELL RESPONSE TO HOST ANTIGENS}

The second phase of acute GVHD includes presentation of host antigens to donor $\mathrm{T}$ cells and the subsequent proliferation and differentiation of these activated $\mathrm{T}$ cells. When a $\mathrm{CD} 4^{+}$cell enters the recipient bloodstream, it will generally interact with the MHC class II molecules of the APCs, whereas a CD8 ${ }^{+}$cell will interact with MHC class I antigens. Data suggest that host APCs are particularly important to the activation of donor T cells (20).

$\mathrm{T}$ cell activation requires two signals. The first signal is provided by the TCR-peptide-MHC interaction $(21,22)$. The second, or costimulatory signal, requires contact with APCs $(23,24)$. The second signal determines the outcome of the activation sequence, leading to either complete activation, partial activation or to a long-lasting state of antigen-specific unresponsiveness, termed anergy. Several ligands can provide costimulation for resting $\mathrm{T}$ cells; the best-characterized costimulatory molecules are the $\mathrm{B} 7$ antigens, which bind to two $\mathrm{T}$ cell surface receptors, CD28, and CTLA-4 $(25,26)$.
T cells that secret IL-2 and interferon- $\gamma$ (IFN- $\gamma$ ) (Type 1 cytokines) are critical mediators of acute GVHD. The importance of GVHD has been demonstrated in both experimental and clinical BMT. First, IL-2 is secreted by donor $\mathrm{CD} 4^{+} \mathrm{T}$ cells in the first days after experimental allogeneic BMT (27). Second, the blockade of IL-2 with antibodies to IL-2 or its receptor can inhibit the development of experimental disease (27). Clinically, the precursor frequency of host-specific, IL-2-producing T cells (precursor frequency of helper $\mathrm{T}$ cells) is predictive for the risk of acute GVHD $(28,29)$. In addition, soluble IL2 receptor levels may be a sensitive indicator of impending GVHD onset, and they correlate with disease severity (30).

Increased serum levels of IFN- $\gamma$ are associated with acute GVHD, and lymphocytes from animals with GVHD secrete significantly greater amounts of IFN- $\gamma$ than lymphocytes from non-GVHD controls (31-35). Additional evidence of a role for IFN- $\gamma$ in experimental acute GVHD includes: priming of macrophages by IFN$\gamma$ during acute GVHD to produce inflammatory cytokines (36); induction of pathology in skin tissues and the gastrointestinal tract by IFN- $\gamma(37,38)$; suppression of T lymphocyte function characteristic of acute GVHD by IFN$\gamma(39,40)$; prevention of acute GVHD when $\mathrm{CD} 8^{+}$cells are incapable of IFN- $\gamma$ production (41); and inhibition of acute GVHD by direct or indirect blockade of IFN- $\gamma$ (37,42-44).

The preincubation of donor $\mathrm{T}$ cells in the presence of the Th2 cytokine IL- 4 can polarize these T cells toward a Th2 cytokine phenotype (43). Transplantation of polarized $\mathrm{Th} 2 \mathrm{~T}$ cell populations failed to induce acute GVHD to MHC class I or class II antigens. These experiments strongly supported the concept that the balance in Th1 and Th2 cytokines is critical for the development (or prevention) of acute GVHD. Further data show that Th2 cells maintain some anti-leukemic efficacy, and can support lymphohematopoietic engraftment $(44,45)$. Peripheral blood hematopoietic cells collected after mobilization with granulocyte colony-stimulating factor (G$\mathrm{CSF}$ ) suggest that $\mathrm{Thl} \rightarrow \mathrm{Th} 2$ polarization may occur, albeit indirectly, resulting in less GVHD compared to saline-treated controls (46-48). This effect also changes the production of other inflammatory cytokines such as TNF- $\alpha(49,50)$.

Regulatory cells may also help determine the ultimate response of donor T cells to host antigens. CD4-CD8 double-negative $\mathrm{T}$ cells (usually NK $1.1^{+}$) can suppress a $\mathrm{T}$ cell response in a mixed lymphocyte reaction (MLR) and can prevent GVHD in vivo. Presumably these regulatory cells develop to control the intensity of the overall response to a specific antigen. The balance between reactive $\mathrm{T}$ cells and suppressor $\mathrm{T}$ cells could thus control the intensity of GVHD. Other potential avenues for tolerance 


\section{ACUTE GVHD PATHOGENESIS}

induction may occur at the cellular level. Groux et al. demonstrated that $\mathrm{CD} 4^{+} \mathrm{T}$ cells, grown ex vivo in the prolonged presence of IL-10, suppressed inflammatory bowel disease that was induced by pathogenic $\mathrm{T}$ cells (51). These cells were termed "Tr1." Moreover, Tr1 cells have been isolated from the peripheral blood of severe combined immunodeficiency (SCID) patients after allogeneic stem cell transplantation, in which high levels of IL-10 in vivo are associated with donor/host tolerance (52). These results suggest that prolonged exposure of naive $\mathrm{CD}^{+}{ }^{+} \mathrm{T}$ cells to IL-10 may result in a population of $\operatorname{Tr} 1$ cells that can regulate immune responses and modulate GVHD.

\section{PHASE THREE: INFLAMMATORY EFFECTORS}

The third phase of acute GVHD is complex, and the precise relationship between cytokines induced during the second phase and mediators of tissue damage during this phase is an area of active investigation. Mononuclear phagocytes, which have been primed with Th1 cytokines during phase two, receive a second, triggering signal to increase the secretion of the inflammatory cytokines TNF- $\alpha$ and IL- 1 . This stimulus may be provided by lipopolysaccharide (endotoxin, LPS), which can leak through the intestinal mucosa damaged by the conditioning regimen. LPS subsequently may stimulate gut-associated lymphocytes and macrophages (36). LPS reaching skin tissues may also stimulate keratinocytes, dermal fibroblasts, and macrophages to produce similar cytokines in the dermis and epidermis (5-7). TNF- $\alpha$ can cause direct tissue damage by inducing necrosis of target cells, or it may induce tissue destruction during GVHD through apoptosis, or programmed cell death. The induction of apoptosis commonly occurs after activation of the TNF- $\alpha-$ Fas antigen pathway (53). Apoptosis is probably critical to GVHD in the large intestine (54), skin $(55,56)$, and possibly in endothelial cells (57). In addition to these proinflammatory cytokines, excess nitric oxide (NO) produced by activated macrophages may contribute to the deleterious effects on GVHD target tissues, particularly immunosuppression $(40,58,59)$. Thus, the induction of inflammatory cytokines may synergize with the cellular damage caused by cytotoxic $\mathrm{T}$ lymphocytes (CTLs) and natural killer (NK) cells $(60,61)$, resulting in the amplification of local tissue injury and further promotion of an inflammatory response.

The gastrointestinal (GI) tract plays a critical role in the amplification of experimental acute GVHD. Damage to the intestinal mucosa in phase 1 and by cytolytic effectors activated in phase 2 allows translocation of LPS from the intestinal lumen into the circulation. LPS sub- sequently stimulates additional cytokine production by gut-associated lymphocytes and macrophages in the GI tract and by keratinocytes, dermal fibroblasts, and macrophages within the skin. This mechanism may amplify local tissue injury and further promote an inflammatory response which, together with the CTL and NK component, leads to target tissue destruction in the BMT host. Damage to the GI tract in phase 3 increases LPS release, which stimulates further cytokine production causing additional GI tract damage. Thus, the GI tract is critical to propagating the "cytokine storm," which is characteristic of acute GVHD.

The histological features of GVHD of the GI tract in clinical GVHD and experimental GVHD following myeloablative conditioning are characterized by villus blunting, lamina propria inflammation, crypt destruction (with crypt stem cell loss), and mucosal atrophy. These features can be induced in animals by the administration of exogenous cytokines, including TNF- $\alpha$ (62) and IL-1 (63). Furthermore, the inhibition of IFN- $\gamma$ (37), TNF- $\alpha$ (64), IL-1 (63), or NO (65) can reduce GI tract histopatholog y in animals with GVHD. In contrast, CTL effectors do not appear to play a dominant role in experimental GVHD of the GI tract $(17,66-70)$, despite the ability of intraepithelial lymphocytes to induce Fas-mediated apoptosis of host-type tumor cells (71).

The role of LPS and inflammatory cytokines in GVHD explain a number of unique and seemingly unrelated aspects of GVHD. For example, a number of analyses of clinical transplants noted increased risks of GVHD associated with advanced-stage leukemia, certain intensive conditioning regimens, and viral infections (14-16). Similarly, the reduction in GVHD seen in gnotobiotic mice $(72,73)$ and in patients with aplastic anemia undergoing transplantation in laminar airflow environments with gut decontamination (74) may be explained by the reduction of bacterial LPS on the skin and gut. The beneficial effect of protective environments may be less apparent in patients receiving transplants for malignancies, because prior therapy and associated infections may have resulted in an environment that facilitates GVHD.

An alternative approach to prevent GI tract damage during allogeneic BMT may permit the exploitation of intensive conditioning as an antileukemic modality without requiring $\mathrm{T}$ cell depletion. One possible approach involves strengthening the GI mucosal barrier before BMT conditioning to prevent entry of immunostimulatory molecules from the GI tract lumen into the circulation. Because direct shielding of the GI tract from total body irradiation (TBI) is not feasible, this effort relies on pharmacological agents that provide a "cytokine shield" to reduce mucosal sensitivity to radiation and/or chemotherapy, This approach is attractive because it blocks inflammatory cytokine dysregulation before the 
initiation of the cascade. In addition, by acting as indirect cytokine antagonists, these shields would not impede the physiological functions of cytokines in cellular differentiation (as might be the case with complete neutralization of TNF- $\alpha$ and IL-1). Two growth factors, IL-11 and keratinocyte growth factor $(17,75-77)$ have recently shown particular promise as cytokine shields.

\section{PHASE THREE: CYTOLYTIC EFFECTORS}

Although cytokines clearly play important roles in the morbidity and mortality of systemic GVHD, they may be less important as mediators of damage in individual GVHD target organs. The unusual cluster of GVHD target organs (skin, gut, and liver) is not adequately explained by the systemic release of cytokines. Furthermore, the absence of GVHD toxicity in other visceral organs, such as the kidneys, argues against circulating cytokines as the sole causation of tissue-specific damage.

Cell-mediated cytotoxicity is thought to contribute to the destruction of GVHD target tissues. T cells can effect cytolysis by either direct contact or the release of soluble mediators such as TNF- $\alpha$. Contact-dependent cell-mediated cytotoxicity can be effected through a secretory pathway involving granule release or by effector cell membrane ligand interaction with death receptors on the membrane of the target cell $(78,79)$. Following secretion of granules by the effector cell, the polymerization of perforin upon binding to the target membrane is crucial to optimize penetration of granule contents, including granzymes A and B, into the targeted cells. Apoptosis of target cells is then rapidly induced by granzyme $\mathrm{B}$ activation of the caspase cascade. A common pathway appears to operate in signaling through so-called death receptors (DR). A number of ligands have been identified on $T$ cells that possess the capability to trimerize TNFR (TNF + receptor)-like DR molecules. In addition to the well-characterized FasL (CD95L)-Fas(CD95) DR ligand-receptor pair, additional molecules, including TWEAK (DR3 li-gand) and TRAIL (DR4,5 ligand), have recently been identified as capable of activating the caspase system and subsequent apoptosis (80-83). Although the physiological function(s) of DR3,4, and 5 are not presently know, the expression of TRAIL and TWEAK on $\mathrm{T}$ cells may be important contributors to this process.

During the past several years, a number of experimental allogeneic BMT studies have used donor inocula that are unable to mediate either perforin/granzyme or FasL-Fas dependent killing (66,84-88). Transplantation of perforin-deficient $\mathrm{T}$ cells results in a marked delay in the onset of weight loss and mortality from GVHD to $\mathrm{MHC}$ and minor $\mathrm{H}$ antigens $(66,84)$. However, these studies also revealed that although greater numbers of per- forin-deficient $\mathrm{T}$ cells were required to induce GVHD with comparable kinetics to that caused by normal $\mathrm{T}$ cells, weight loss and mortality could be induced in the absence of perforin-dependent killing. Moreover, the clinical signs of GVHD including kyphosis, alopecia, skin lesions, and diarrhea, as well as histopatholog ical changes in the skin, liver, and lymphohematopoietic compartment, were all eventually observed following transplant of perforin-deficient $\mathrm{T}$ cells $(66,84)$. Thus, it is now clear that the perforin/granzyme pathway is not necessary to generate tissue damage.

Perforin-deficient $\mathrm{T}$ cells retain the capacity to mediate FasL-dependent killing. Accordingly, experiments have been performed to examine the consequences of transplanting donor cells unable to signal Fas-mediated apoptosis. These studies have utilized $\mathrm{T}$ cells from mice with a naturally occurring genetic mutation resulting in a FasL protein $(\mathrm{gld} / \mathrm{gld})$ that cannot trimerize Fas, and therefore fails to induce Fas signaling (89). Transplantation of donor $\mathrm{T}$ cells with functionally defective FasL into lethally irradiated MHC-matched allogeneic recipients resulted in the induction of weight loss and lethality (66). In contrast to the findings using perforin-deficient cells, transplantation of comparable numbers of FasL-defective $\mathrm{T}$ cells versus wild-type $\mathrm{T}$ cells resulted in only a modest delay in weight loss and a small increase in median survival time (66). Thus, the presence of perforin and other potential effector pathways in the gld $\mathrm{T}$ cells were capable of inducing cachexia and lethality of GVHD $(66,87)$.

FasL-mediated cytotoxity may be an important effector pathway in hepatic GVHD. First, hepatic GVHD has been found to be markedly diminished following transplant of FasL-defective $T$ cells and normal marrow. In the absence of donor-mediated FasL-dependent cytotoxicity, minimal liver inflammation was observed in two minor histocompatibility antigens (MiHA) disparate BMT models (66). Compatible with this notion, a recent study reported that administration of anti-FasL (but not anti-TNF antibody) significantly blocked the hepatic in a model of GVHD to MHL antigens (69).

In summary, recent investigations have begun to define the contributions of cell-mediated cytotoxicity via both perforin/granzyme and FasL-dependent pathways to both systemic GVHD and to GVHD target organ damage. The newly emerging molecular pathways of death signals should provide more complete and precise definitions of requirements for GVHD-induced pathogenesis. Because $\mathrm{CD} 4^{+}$and $\mathrm{CD} 8^{+}$cells can mediate both GVHD and GVL activity, assessing the relative contributions of each of the cytotoxic pathways in individual subsets may help in the potential dissociation of GVHD from GVL. As our understanding of the relative contribution of each of these pathways to GVHD pathology in 


\section{ACUTE GVHD PATHOGENESIS}

individual GVHD target organs deepens, novel strategies to optimize prophylaxis and therapy for individual host tissues may emerge.

\section{REFERENCES}

1. Antin JH and JLM Ferrara. (1992). Cytokine dysregulation and acute graft-versus-host disease. Blood 80:2964-2968.

2. Jadus MR and HT Wepsic. (1992). The role of cytokines in graft-versus-host reactions and disease. Bone Marrow Transplant 10:1-14.

3. Krenger W and JLM Ferrara. (1996). Dysregulation of cytokines during graft-versus-host disease. J. Hematother 5:3-14.

4. Xun CQ, JS Thompson, CD Jennings, SA Brown and MB Widmer. (1994). Effect of total body irradiation, busulfancyclophosphamide, or cyclophosphamid e conditioning on inflammatory cytokine release and development of acute and chronic graft-versus-host disease in $\mathrm{H}$-2-incompatible transplanted SCID mice. Blood 83:2360-2367.

5. Luger TA and T Schwarz. (1990). Evidence for an epidermal cytokine network. J. Invest. Dermatol 95 (6 suppl.): 100s.

6. McKenzie R and D Sauder. (1990). The role of keratinocyte cytokines in inflammation and immunity. J. Invest. Dermatol. 95:105s-107s.

7. Kupper T. (1990). Immune and inflammatory processes in cutaneous tissues. Mechanisms and speculations. J. Clinical Invest 86:1783-1789.

8. Norton J and JP Sloane. (1991). ICAM-1 expression on epidermal keratinocytes in cutaneous graft-versus-host disease. Transplant 51:1203.

9. Cavender DE, DO Haskard, B Joseph and M Ziff. (1986). Interleukin-1 increases the binding of human B and $\mathrm{T}$ lymphocytes to endothelial cell monolayers. J. Immunol. 136:203-207.

10. Chang RJ and SH Lee. (1986). Effects of interferon-gamm a and tumor necrosis factor-alpha on the expression of an Ia antigen on a murine macrophage cell line. J. Immunol. 137:2853-2856.

11. Leeuwenberg JF, J Van Damme, T Maeger, TM Jeunhomme and WA Buurman. (1988). Effects of tumor necrosis factor in the interferon-gamma-induced major histocompatibility complex class II antigen expression by human endothelial cells. Eur. J. Immunol. 18:1469-1472.

12. Pober JS, MA Gimbrone, LA Lapierre, DL Mendrick, W Fiers, R Rothlein and TA Springer. (1986). Overlapping patterns of activation of human endothelial cells by interleukin-1, tumor necrosis factor, and immune interferon. $\underline{\mathrm{J}}$. Immunol. 37:1893-1896.

13. Thornhill MH, SM Wellicome, DL Mahiouz, JSS Lanchbury, U Kyan-Aung and DO Haskard. (1991). Tumor necrosis factor combines with IL-4 or IFN- $\gamma$ to selectively enhance endothelial cell adhesiveness for T cells. J. Immunol. 46:592-598.

14. Clift RA, CD Buckner, FR Appelbaum, SI Bearman, FB Petersen, LB Fisher, C Anasetti, P Beatty, WI Bensinger and K Doney. (1990). Allogeneic marrow transplantation in patients with acute myeloid leukemia in first remission: a randomized trial of two irradiation regimens. Blood 76:1867-1871.

15. Gale RP, MM Bortin, DW van Bekkum, JC Biggs, KA Dicke, E Gluckman, RA Good, RG Hoffmann, HE Kay and JH Kersey. (1987). Risk factors for acute graft-versushost disease. Br. J. Haematol. 67:397-406.

16. Ringden O. (1990). Viral infections and graft-vs.-host disease. In: Graft-vs.-Host Disease. SJ Burakoff, HJ Deeg, J Ferrara, and K Atkinson, eds. Marcel Dekker, New York, p. 467.

17. Hill GR, JM Crawford, KJ Cooke, YS Brinson, L Pan and JLM Ferrara. (1997). Total body irradiation effects on acute graft versus host disease. The role of gastrointestinal damage and inflammatory cytokines. Blood 90:3204-3213.

18. Johnson BD, WD Drobisky and RL Truitt. (1993). Delayed infusion of normal donor cells after MHC-matched bone marrow transplantation provides an anti-leukemia reaction without graft-versus-host disease. Bone Marrow Transpl. 11:329-336.

19. Johnson BD and RL Truitt. (1995). Delayed infusion of immunocompetent donor cells after bone marrow transplantation breaks graft-host tolerance and allows for persistent antileukemic reactivity without severe graft-versus-host disease. Blood 85:3302-3312.

20. Shlomchik WD, MS Couzens, BT Cheng and SG Emerson. (1997). Radioresistant host antigen presenting cells are required for acute graft-versus-host disease induction. Blood (suppl) 90:396a.

21. Sette A, J Alexander and H Grey. (1995). Interaction of antigenic peptides with MHC and TCR molecules. Clin. Immunol. Immunopatho 1. 76:168-171.

22. Sakihama T, A Smolyar and E Reinherz. (1995). Molecular recognition of antigen involves lattice formation between CD4, MHC class II and TCR molecules. Immunol Today 16:581-7.

23. Yang Y and JM Wilson. (1996). CD40 ligand-dependent $\mathrm{T}$ cell activation: requirement of B7-CD28 signaling through CD40. Science 273:1862-1864.

24. June $\mathrm{CH}$, JA Bluestone, LM Nadler and CB Thompson. (1994). The B7 and CD28 receptor families. Immunol. Today 15(7):321-331.

25. Green JM, PJ Noel, AI Sperling, TL Walunas, GS Gray, JA Bluestone, et al. (1994). Absence of B7-dependent responses in CD28-deficient mice. Immunity 1:501-508.

26. Freeman GJ, JG Gribben, VA Boussiotis, JW Ng, VA Restivo, LA Lombard, GS Gray and LM Nadler. (1993). Cloning of B7-2: A CTLA4 counter receptor that costimulates human T cell proliferation. Science 262:909-911.

27. Via CS and FD Finkelman. (1993). Critical role of interleukin-2 in the development of acute graft-versus-host disease. Int. Immunol. 5:565-572.

28. Theobald M, T Nierle, D Bunjes, R Arnold and H Heimpel. (1992). Host-specific interleukin-2-secr eting donor Tcell precursors as predictors of acute graft-versus-host disease in bone marrow transplantation between HLAidentical siblings. N. Engl. J. Med. 327:1613-1617.

29. Schwarer AP, YZ Jiang, PA Brookes, AJ Barrett, JR B atchelor, JM Goldman and RI Lechler. (1993). Frequency of 
anti-recipient alloreactive helper T-cell precursors in donor blood and graft-versus-host disease after HLA-identical sibling bone-marrow transplantation. Lancet 341:203-205.

30. Miyamoto T, K Akashi, S Hayashi, $\mathrm{H}$ Gondo, $\mathrm{M} \mathrm{Mu}$ rakawa, K Tanimoto, M Harada and Y Niho. (1996). Serum concentration of the soluble interleukin-2 receptor for monitoring acute graft-versus-host disease. Bone Marrow Transpl. 17:185-190.

31. Szebeni J, MG Wang, DA Pearson, GL Szot, and M Sykes. (1994). IL-2 inhibits early increases in serum gamma interferon levels associated with graft-versus-host disease. Transplantation 58:1385-1393.

32. Wang MG, J Szebeni, DA Pearson, GL Szot and M Sykes. (1995). Inhibition of graft-versus-host disease by interleukin-2 treatment is associated with altered cytokine production by expanded graft versus host reactive $\mathrm{CD}^{+}$ helper cells. Transplantation 60:481-490.

33. Troutt AB, E Maraskovsky, LA Rogers, MH Pech and A Kelso. (1992). Quantitative analysis of lymphokine expression in vivo and in vitro. Immunol. Cell Biol. 70:51-57.

34. Allen RD, TA Staley and CL Sidman. (1993). Differential cytokine expression in acute and chronic murine graft-versus-host disease. Eur. J. Immunol. 23:333-337.

35. Ferrara JLM, KR Cooke, L Pan and W Krenger. (1996). The immunopathophysiology of acute graft-versus-host disease. Stem Cells 14:473-489.

36. Nestel FP, KS Price, TA Seemayer and WS Lapp. (1992). Macrophage priming and lipopolysaccharid e-triggered release of tumor necrosis factor alpha during graft-versushost disease. J. Exp. Med 175:405-413.

37. Mowat A. (1989). Antibodies to IFN-gamma prevent immunological mediated intestinal damage in murine graftversus-host reactions. Immunology 68:18-24.

38. Dickinson AM, L Sviland, J Dunn, P Carey and SJ Proctor. (1991). Demonstration of direct involvement of cytokines in graft-versus-host reactions using an in vitro skin explant model. Bone Marrow Transplant. 7:209-216.

39. Huchet R, M Bruley-Rosset, C Mathiot, D Grandjon and O Halle-Pannenk o. (1993). Involvement of IFN-gamma and transform ing growth factor-beta in graft-vs-host reaction-associated immunosuppression. J. Immunol. 150: 2517-2524.

40. Krenger W, G Falzarano, J Delmonte, KM Snyder, JCH Byon and JLM Ferrara. (1996). Interferon- $\gamma$ suppresses Tcell proliferation to mitogen via the nitric oxide pathway during experimental acute graft-versus-host disease. Blood 88:1113-1121.

41. Rus V, A Svetic, P Nguyen, WC Gause and CS Via. (1995). Kinetics of Th1 and Th2 cytokine production during the early course of acute and chronic murine graft-versus-host disease. J. Immunol. 155:2396-2406.

42. Brok HPM, PJ Heidt, PH van der Meide, C Zurcher and JM Vossen. (1993). Interferon- $\gamma$ prevents graft-versus-host disease after allogeneic bone marrow transplantation in mice. J. Immunol. 151:6451-6459.

43. Krenger W, KM Snyder, CH Byon, G Falzarano and JLM Ferrara. (1995). Polarized type 2 alloreactive CD4+ and CD8+ donor T cells fail to induce experimental acute graftversus-host disease. J. Immunol. 155:585-593.
44. Fowler DH, K Kurasawa, A Husebekk, PA Cohen and RE Gress. (1994). Cells of the Th2 cytokine phenotype prevent LPS-induced lethality during murine graft-versus-host reaction. J. Immunology 152:1004-1011.

45. Fowler DH, K Kurasawa, R Smith, MA Eckhaus and RE Gress. (1994). Donor CD4-enriched cells of Th2 cytokine phenotype regulate graft-versus-host disease without impairing allogeneic engraftment in sublethally irradiated mice. Blood 84:3540-3549.

46. Pan L, J Delmonte, CK Jalonen and JLM Ferrara. (1995). Pretreatment of donors with granulocyte colony-stimulating factor polarizes donor T lymphocytes toward type $2 \mathrm{cy}-$ tokine production and reduces severity of experimental graft versus host disease. Blood 86:4422-4429.

47. Pan L, KR Bressler, KR Cooke, W Krenger, M Karandikar and JLM Ferrara. (1996). Long-term engraftment, graftversus-host disease, and immunologic reconstitution following experimental transplantation of allogeneic peripheral blood cells from G-CSF treated donors. Biol. Blood Marrow Transplant. 3:126-133.

48. Zeng D, S Dejbakhsh-Jones and S Strober. (1997). Granulocyte colony-stimulating factor reduces the capacity of blood mononuclear cells to induce graft-versus-host disease: impact on blood progenitor cell transplantation. Blood 90:453-463.

49. Kitabayashi A, M Hirokawa, Y Hatano, M Lee, J Kuroki, H Niitsu and AB Miura. (1995). Granulocyte colony stimulating factor downregulates allogeneic immune response by posttranscriptiona 1 inhibition of tumor necrosis factor$\alpha$ production. Blood 86:2220-2227.

50. Pan L, T Teshima, G Hill, D Bungard, Y Brinson, V Reddy, KR Cooke and JLM Ferrara. (1999). G-CSF mobilized allogeneic stem cell transplantation maintains GVL effects through a perforin dependent pathway while preventing GVHD. Blood 93:4071-4078.

51. Groux H, A O'Garra, M Bigler, M Rouleau, S Antonenko, $\mathrm{J}$ de Vries and MG Roncarolo. (1997). A CD4 ${ }^{+}$T cell subset inhibits antigen specific $\mathrm{T}$ cell responses and prevents colitis. Nature 389:737-742.

52. Bacchetta R, M Bigler, JL Touraine, R Parkman, PA Tovo, J Abrams, R de Waal Malefyt, JE de Vries and MG Roncarolo. (1994). High levels of interleukin 10 production in vivo are associated with tolerance in SCID patients transplanted with HLA mismatched hematopoietic stem cells. J. Exp. Med. 179:493-502.

53. Laster SM, JG Wood and LR Gooding. (1988). Tumor necrosis factor can induce both apoptotic and necrotic forms of cell lysis. J. Immunol. 141:2629-2634.

54. Suzuki M, Y Suzuki, H Ikeda, M Koike, M Nomura, J Tamura, S Sato, Y Hotta and G Itoh. (1994). Apoptosis of murine large intestine in acute graft-versus-host disease after allogeneic bone marrow transplantation across minor histocompatibilit y barriers. Transplantation 57:1284-1287.

55. Langley R, N Walsh, T Nevill, L Thomas and G Rowden. (1996). Apoptosis is the mode of keratinocyte death in cutaneous graft-versus-host disease. J. Am. Acad. Dermatol. 35:187-190.

56. Gilliam AC, D Whitaker-Menezes, R Korngold and GF Murphy. (1996). Apoptosis is the predominant form of ep- 


\section{ACUTE GVHD PATHOGENESIS}

ithelial target cell injury in acute experimental graft-versus-host disease. J. Invest. Dermatol. 107(3):377-383.

57. Lindner H, E Holler, B Erti, G Multhoff and $M$ Schreglmann. (1997). Peripheral blood mononuclear cells induce programmed cell death in human endothelial cells and may prevent repair: role of cytokines. Blood 89:1931-1938.

58. Langrehr JM, N Murase, PM Markus, X Cai, P Neuhaus, W Schraut, RL Simmons and RA Hoffman. (1992). Nitric oxide production in host-versus-graft and graft-versus-host reactions in the rat. J. Clin. Invest. 90:679-683.

59. Falzarano G, W Krenger, KM Snyder, J Delmonte, M Karandikar and JLM Ferrara. (1996). Suppression of B cell proliferation to lipopolysaccharid e is mediated through induction of the nitric oxide pathway by tumor necrosis factor-a in mice with acute graft-versus-host disease. Blood 87:2853-2860.

60. Ghayur T, TA Seemayer, PAL Kongshawn, JS Gartner and WS Lapp. (1987). Graft-versus-host (GVH) reactions in the beige mouse: an investigation of the role of host and donor natural killer cells in the pathogenesis of GVH disease. Transplantation 44:261-267.

61. Hakim FT, SO Sharrow, S Payne and GM Shearer. (1991). Repopulation of host lymphohematopoietic systems by donor cells during graft-versus-host reaction in unirradiated adult F1 mice injected with parental lymphocytes. J. Immunol. 146:2108-2115.

62. Garside P, C Bunce, R Tomlinson, B Nichois and A Mowat. (1994). Analysis of the enteropathic effects of tumour necrosis factor $\alpha$. Cytokine 5:24-30.

63. Mowat A, A Hutton, P Garside and M Steel. (1993). A role for IL- $1 \alpha$ in immunologically mediated enteropathy. Immunology 80:110-115.

64. Piguet PF, GE Grau, B Allet and PJ Vassalli. (1987). Tumor necrosis factor/cachectin is an effector of skin and gut lesions of the acute phase of graft-versus-host disease. J. Exp. Med. 166:1280-1289.

65. Garside P, AK Hutton, A Severn, FY Liew and AM Mowat. (1992). Nitric oxide mediates intestinal pathology in graftvs-host disease. Eur. J. Immunol. 22:2141-2145.

66. Baker MB, NH Altman, ER Podack and RB Levy. (1996). The role of cell-mediated cytotoxicity in acute GVHD after MHC-matched allogeneic bone marrow transplantation in mice. J. Exp. Med. 183:2645-2656.

67. Hill G, T Teshima, A Gerbitz, L Pan, K Cooke, Y Brinson, JM Crawford and JLM Ferrara. (1999). Differential roles of IL-1 and TNF $\alpha$ on graft-versus-host disease and graft versus leukemia. J. Clin. Invest. 104:459-467.

68. Cooke KR, G Hill, JM Crawford, D Bungard, Y Brinson, J Delmonte Jr and JLM Ferrara. (1998). TNF $\alpha$ production to LPS stimulation by donor cells predicts the severity of experimental acute graft-versus-host disease. J. Clin. Invest. 102:1882-1891.

69. Hattoti K, T Hirano, H Miyajima, N Yamakawa, MD Tateno, K Oshimi, N Kayagaki, H Yagita and K Okumura. (1998). Differential effects of anti-fas ligand and anti-tumor necrosis factor a antiboides on acute graft-versus-host disease pathologies. Blood 91:4051-4055.

70. Thiele D, M Eigenbrodt, S Bryde, E Eigenbrodt and P Lip- sky. (1989). Intestinal graft-versus-host disease is initiated by donor $\mathrm{T}$ cells distinct from classic cytotoxic $\mathrm{T}$ lymphocytes. J. Clinical Invest. 84:1947-1956.

71. Lin T, T Brunner, B Tietz, J Madsen, E Bonfoco, M Reaves, M Huflejt and DR Green. (1998). Fas ligand-mediated killing by intestinal intraepithelial lymphocytes. J. Clin. Invest. 101:570-577.

72. Jones JM, R Wison and PM Bealmear. (1971). Mortality and gross pathology of secondary disease in germfree mouse radiation chimeras. Radiat. Res. 45:577-588.

73. van Bekkum D, J Roodenburg, P Heidt and D van der Waaj. (1974). Mitigation of secondary disease of allogenic mouse radiation chimeras by modification of the intestinal microflora. J Natl. Cancer Inst. 52:401.

74. Storb R, RL Prentice, CD Buckner, RA Clift, F Appelbaum, J Deeg, K Doney, JA Hansen, M Mason, JE Sanders, J Singer, KM Sullivan, RP Witherspoon and ED Thomas. (1983). Graft-versus-hos t disease and survival in patients with aplastic anemia treated by marrow grafts from HLAidentical siblings. Beneficial effect of a protective environment. N. Engl. J. Med. 308:302-307.

75. Teshima T, G Hill, L Pan, Y Brinson, $M$ van den Brink, $\mathrm{K}$ Cooke and JLM Ferrara. (1999). Interleukin-11 separates graft-versus-leukem ia effects from graft-versus-host disease after bone marrow transplantation. J. Clin. Invest. 104:317-25.

76. Krijanovski O, Hill G, Cooke K, Teshima T, Brinson Y and Ferrara J. (1999). Keratinocyte growth factor (KGF) separates graft versus leukemia effects from graft-versushost disease. Blood 94:825-831.

77. Panoskaltsis-Mortari A, D Lacey, D Vallera and B Blazer. (1998). Keratinocyte growth factor administered before conditioning ameliorates graft-versus-host disease after allogeneic bone marrow transplantation in mice. Blood 92:3960-3967.

78. Lowin B, M Hahne, C Mattmann, and J Tschopp. (1994). Cytolytic T-cell cytotoxicity is mediated through perforin and Fas lytic pathways. Nature 370:650-652.

79. Kagi D, F Vignaux, B Ledermann, K Burki, V Depraetere, S Nagata, et al. (1994). Fas and perforin pathways as major mechanisms of $\mathrm{T}$ cell-mediated cytotoxicity. Science 265:528-530.

80. Chinnaiyan A, K O'Rourke, G Yu, R Lyons, M Garg, D Duan, L Xing, R Gentz, J Ni and VM Dixit. (1996). Signal transduction by DR3, a death domain-containing receptor related to TNFR-1 and CD95. Science 274:990-992.

81. Chicheportiche Y, P Bourdon, H Xu, Y Hsu, H Scott, C Hession, I Garcia and JL Browning. (1997). TWEAK, a new secreted ligand in the tumor necrosis factor family that weakly induces apoptosis. J. Biol. Chem. 272:3240134210.

82. Pan G, K O'Rourke, AM Chinnaiyan, R Gentz and R Ebner. (1997). The receptor for the cytotoxic ligand TRAIL. Science 276:111-113.

83. Sheridan J, S Marsters, R Pitti, A Gurney, M Skubatch, D Baldwin, L Ramakrishnan, CL Gray, K Baker, WI Wood, AD Goddard, P Godowski and A Ashkenazi. (1997). Control of TRAIL-induced apoptosis by a family of signaling and decoy receptors. Science 277:818-821. 


\section{FERRARA}

84. Levy RB, M Baker and ER Podack. (1995). Perforin-deficient $\mathrm{T}$ cells can induce acute graft-versus-host disease after transplantation of MHC-matched or MHC disparate allogeneic bone marrow. Ann. NY Acad. Sci. 770:366-377.

85. Graubert TA, JH Russell and T Ley. (1996). The role of granzyme $\mathrm{B}$ in murine models of acute graft-versus-host disease and graft rejection. Blood 87:1232-1237.

86. Baker MB, RL Riley, ER Podack and RB Levy. (1997). GVHD-associated lymphoid hypoplasia and B cell dysfunction is dependent upon donor T cell-mediated Fas-ligand function, but not perforin function. Proc. Natl. Acad. Sci. USA 94:1366-1371.

87. Via C, P Nguyen, A Shustov, J Drappa and K Elkon. (1996). A major role for the Fas pathway in acute graftversus-host disease. J. Immunol. 157:5387-5393.

88. Graubert T, J Dipersio, J Russell and T Ley. (1997). Perforin/granzyme-depen dent and independent mechanisms are both important for the development of graft-versus-host disease after murine bone marrow transplantation. J. Clin. Invest. 100:904-911.

89. Takahashi T, M Tanaka, CI Brannan, NA Jenkins, NG Copeland and T Suda. (1994). Generalized lymphoproliferative disease in mice, caused by a point mutation in the Fas ligand. Cell 76:969-976.

Address reprint requests to: James L.M. Ferrara, M.D. 1500 E. Medical Center Drive CCGC 6308 Ann Arbor, MI 48109-0942

E-mail: ferrara@umich.edu 


\section{This article has been cited by:}

1. M. A. King, L. Covassin, M. A. Brehm, W. Racki, T. Pearson, J. Leif, J. Laning, W. Fodor, O. Foreman, L. Burzenski, T. H. Chase, B. Gott, A. A. Rossini, R. Bortell, L. D. Shultz, D. L. Greiner. 2009. Human peripheral blood leucocyte non-obese diabetic-severe combined immunodeficiency interleukin-2 receptor gamma chain gene mouse model of xenogeneic graft- versus -host-like disease and the role of host major histocompatibility complex. Clinical \& Experimental Immunology 157:1, 104-118. [CrossRef]

2. R. Shah, S. T. Selby, B. Yokley, R. S. Slack, C. K. Hurley, P. E. Posch. 2009. TNF , LTA and TGFB1 genotype distributions among acute graft- vs -host disease subsets after HLA-matched unrelated hematopoietic stem cell transplantation: a pilot study. Tissue Antigens 74:1, 50-56. [CrossRef]

3. J Tsuchiyama, T Yoshino, T Saito, T Furukawa, K Ito, I Fuse, Y Aizawa. 2009. Cutaneous lymphocyte antigen-positive $\mathrm{T}$ cells may predict the development of acute GVHD: alterations and differences of CLA+ T- and NK-cell fractions. Bone Marrow Transplantation 43:11, 863-873. [CrossRef]

4. W.S. Bartynski. 2008. Posterior Reversible Encephalopathy Syndrome, Part 2: Controversies Surrounding Pathophysiology of Vasogenic Edema. American Journal of Neuroradiology 29:6, 1043-1049. [CrossRef]

5. Sven Kohler, Andreas Pascher, Guido Junge, Igor M. Sauer, Marion Nagy, Constanze Schönemann, Martin Koch, Ulf Neumann, Johann Pratschke, Peter Neuhaus. 2008. Graft versus host disease after liver transplantation - a single center experience and review of literature. Transplant International 21:5, 441-451. [CrossRef]

6. Neena Kapoor. 2008. Graft-versus-host disease and immunosuppression. Immunologic Research 41:1, 34-44. [CrossRef]

7. W.S. Bartynski, J.F. Boardman. 2008. Catheter Angiography, MR Angiography, and MR Perfusion in Posterior Reversible Encephalopathy Syndrome. American Journal of Neuroradiology 29:3, 447-455. [CrossRef]

8. J. W. Chien, M. J. Boeckh, J. A. Hansen, J. G. Clark. 2008. Lipopolysaccharide binding protein promoter variants influence the risk for Gram-negative bacteremia and mortality after allogeneic hematopoietic cell transplantation. Blood 111:4, 2462-2469. [CrossRef]

9. W.S. Bartynski, H.P. Tan, J.F. Boardman, R. Shapiro, J.W. Marsh. 2008. Posterior Reversible Encephalopathy Syndrome after Solid Organ Transplantation. American Journal of Neuroradiology 29:5, 924-930. [CrossRef]

10. Y S Chae, S K Sohn, J G Kim, Y Y Cho, J H Moon, H J Shin, J S Chung, G J Cho, D H Yang, J-J Lee, Y-K Kim, H-J Kim. 2007. New myeloablative conditioning regimen with fludarabine and busulfan for allogeneic stem cell transplantation: comparison with BuCy2. Bone Marrow Transplantation 40:6, 541-547. [CrossRef]

11. S Hingorani, K A Guthrie, G Schoch, N S Weiss, G B McDonald. 2007. Chronic kidney disease in long-term survivors of hematopoietic cell transplant. Bone Marrow Transplantation 39:4, 223-229. [CrossRef]

12. Jon M. Sweany, Walter S. Bartynski, John F. Boardman. 2007. "Recurrent" Posterior Reversible Encephalopathy Syndrome. Journal of Computer Assisted Tomograpby 31:1, 148-156. [CrossRef]

13. Ladan Kobari, Marie C. Giarratana, Jean C. Gluckman, Luc Douay, Michelle Rosenzwajg. 2006. Ex Vivo Expansion Does Not Alter the Capacity of Umbilical Cord Blood CD34 + Cells to Generate Functional T Lymphocytes and Dendritic Cells. Stem Cells 24:9, 2150-2157. [CrossRef]

14. Jacques-Olivier Bay, Nathalie Dh??din, Martin Goerner, Jean-Pierre Vannier, Aude Marie-Cardine, Aspasia Stamatoullas, Jean-Pierre Jouet, Ibrahim Yakoub-Agha, Reza Tabrizi, Catherine Faucher, Jose-Luis Diez-Martin, Gomez Nunez, Rocio Parody, No??! Milpied, Hel??ne Esp??rou, Fr??d??ric Garban, Claire Galambrun, Fabrice Kwiatkovski, Isabelle Darlavoix, Amina Zina??, Alain Fischer, Mauricette Michallet, Jean-Paul Vernant. 2005. Inolimomab in Steroid-Refractory Acute Graft-versus-Host Disease Following Allogeneic Hematopoietic Stem Cell Transplantation: Retrospective Analysis and Comparison with Other Interleukin-2 Receptor Antibodies. Transplantation 80:6, 782-788. [CrossRef]

15. S-Q Ji, H-R Chen, H-M Yan, H-X Wang, J Liu, P-y Zhu, M-h Xiao, C-Q Xun. 2005. Anti-CD25 monoclonal antibody (basiliximab) for prevention of graft-versus-host disease after haploidentical bone 
marrow transplantation for hematological malignancies. Bone Marrow Transplantation 36:4, 349-354. [CrossRef]

16. M Mabed, S Maroof, K Zalta, M El-Awadee. 2005. Delayed or delayed sequential bone marrow transplantation: relevance for acute graft-versus-host disease prevention after major $\mathrm{H} 2$ incompatible transplantation. Bone Marrow Transplantation 35:8, 803-806. [CrossRef]

17. M Mohty, C Faucher, D Blaise. 2005. Graft-versus-host-disease and granulocyte colony-stimulating factor administration after allogeneic stem cell transplantation. Leukemia . [CrossRef]

18. Michael B. Maris, Rainer Storb. 2005. Allogeneic Hematopoietic Cell Transplantation as Consolidation Immunotherapy of Cancer after Autologous Transplantation. Acta Haematologica 114:4, 221-229. [CrossRef]

19. C. V. Navarrete. 2004. ES03.03 Immunity and transplantation. Vox Sanguinis 87:s1, 39-42. [CrossRef]

20. Andrew M. Yeager. 2004. Editorial Overview: Reduced-intensity allogeneic hematopoietic cell transplantation: shifting paradigms, new definitions, new challenges. Current Opinion in Organ Transplantation 9:1, 36-38. [CrossRef]

21. R. Srinivasan, S. Chakrabarti, T. Walsh, T. Igarashi, Y. Takahashi, D. Kleiner, T. Donohue, R. Shalabi, C. Carvallo, A. J. Barrett, N. Geller, R. Childs. 2004. Improved survival in steroid-refractory acute graft versus host disease after non-myeloablative allogeneic transplantation using a daclizumab-based strategy with comprehensive infection prophylaxis. British Journal of Haematology 124:6, 777-786. [CrossRef]

22. Charles Mullighan, Sue Heatley, Kathleen Doherty, Ferenc Szabo, Andrew Grigg, Timothy Hughes, Anthony Schwarer, Jeff Szer, Brian Tait, Bik To, Peter Bardy. 2004. Non-HLA immunogenetic polymorphisms and the risk of complications after allogeneic hemopoietic stem-cell transplantation. Transplantation 77:4, 587-596. [CrossRef]

23. David Nachbaur, Brigitte Kircher, Klaus Eisendle, Karla Latzer, Margot Haun, Gunther Gastl. 2003. Phenotype, function and chimaerism of monocyte-derived blood dendritic cells after allogeneic haematopoietic stem cell transplantation. British Journal of Haematology 123:1, 119-126. [CrossRef]

24. Jennifer E. Schwartz, Andrew M. Yeager. 2003. Reduced-intensity allogeneic hematopoietic cell transplantation: Graft versus tumor effects with decreased toxicity. Pediatric Transplantation 7:3, 168-178. [CrossRef]

25. Frederick R. Appelbaum. 2002. Hematopoietic Cell Transplantation as a Form of Immunotherapy. International Journal of Hematology 75:3, 222-227. [CrossRef]

26. Brigitte Kircher, Stefan Stevanovic, Martina Urbanek, Andrea Mitterschiffthaler, Hans-Georg Rammensee, Kurt Grunewald, Gunther Gastl, David Nachbaur. 2002. Induction of HA-1-specific cytotoxic T-cell clones parallels the therapeutic effect of donor lymphocyte infusion. British Journal of Haematology 117:4, 935-939. [CrossRef]

27. Yi Zhang, Jean-Pierre Louboutin, Jiang Zhu, Adam J. Rivera, Stephen G. Emerson. 2002. Preterminal host dendritic cells in irradiated mice prime CD8+ T cell-mediated acute graft-versus-host disease. Journal of Clinical Investigation 109:10, 1335-1344. [CrossRef]

28. Rainer Ordemann, Raymond Hutchinson, Jeffrey Friedman, Steven J. Burakoff, Pavan Reddy, Ulrich Duffner, Thomas M. Braun, Chen Liu, Takanori Teshima, James L.M. Ferrara. 2002. Enhanced allostimulatory activity of host antigen-presenting cells in old mice intensifies acute graft-versus-host disease. Journal of Clinical Investigation 109:9, 1249-1256. [CrossRef]

29. F. Baron , Y. Beguin . 2002. Nonmyeloablative Allogeneic Hematopoietic Stem Cell TransplantationNonmyeloablative Allogeneic Hematopoietic Stem Cell Transplantation. Journal of Hematotherapy Stem Cell Research 11:2, 243-263. [Abstract] [PDF] [PDF Plus]

30. Takanori Teshima, James Ferrara. 2001. Current Opinion in Organ Transplantation 6:3, 265-271. [CrossRef]

31. Guadalupe Martínez-Jaramillo, Enrique Gómez-Morales, Elizabeth Sánchez-Valle , Hector Mayani . 2001. Severe Hematopoietic Alterations In Vitro, in Bone Marrow Transplant Recipients Who Develop Graft-Versus-Host DiseaseSevere Hematopoietic Alterations In Vitro, in Bone Marrow Transplant Recipients 
Who Develop Graft-Versus-Host Disease. Journal of Hematotherapy Stem Cell Research 10:3, 347-354. [Abstract] [PDF] [PDF Plus] 